\title{
Comparison Of Pangkah Kulon Village, Gresik Regency With Intan Jaya Village, Kampar Regency In Public Service In 2017
}

\author{
Ahmad Fitra Yuza \\ Major of Government Science Islam University, \\ Riau, Indonesia \\ Nandang Alamsah Deliarnoor \\ Department of Government Science Padjadjaran University, \\ Bandung, Indonesia \\ Nasrullah Nazsir \\ Department of Government Science Padjadjaran University, \\ Bandung, Indonesia \\ Priyo Teguh \\ Institute of Public Administration, \\ Bandung, Indonesia
}

\begin{abstract}
This study discusses the comparison of two village administrations in implementing public service, especially village level demography services. Service at village level is very urgent consider the village is a semi-autonomous government. The position of village government in the service of population administration based on the principle of assistance, is set forth in Law Number 24 Year 2013 regarding the amendment to Law Number 23 of 2006 concerning the administration of population in Article 7 Paragraph (1) Point $f$ reads that the assignment to the village to organize some of the administrative affairs of population based on the principle of co-administration. Pangkah Kulon, a village located in Gresik Regency has the best service innovation to the local community, meanwhile the Village Intan Jaya, in Kampar regency, was far from service standards. Methods and research approaches were conducted using qualitative research method with a descriptive approach, data collection through observation method, in-depth interview, documentation and focus group discussion. Informant determination technique was done by criterion-based selection technique. The results of the research indicate that the service of Intan Jaya Village cannot be well organized which is seen from not fulfilling the standard of service, the service procedure which is difficult to be understood by the society, the recruitment of old system employees, the absence of service innovation, the absence of system in response to various complaints of society, service layout.
\end{abstract}

Keywords: village government comparison, public service, service procedures.

INTRODUCTION

Administration of population administration services at the village level in the form of making a certificate to the publication at the last level as an administrative product. According to Nurcholis (2011: 105) public services provided by the village government of which provide population services. Furthermore, Nurcholis (2017: 7) describes the village government to mediate intermediaries between the population who need public documents such as ID cards, family card or other authentic certificates. As a mandate from the state that every citizen 
should be recorded as regulated by law. Being a citizen and a citizen is the basic and ultimate right of every citizen. They have the right to live, self-determination, freedom of religion and settling in a territory or country. Constitutionally this right has been explicitly regulated in Chapter X on citizens and residents, Article 26, 27, 28 and 29 of the Indonesian Constitution 1945 (UUD 1945) as one of the basic rules of population regulations.

The process of population administration service in accordance with Law Number 24 Year 2013 regarding the amendment to Law Number 23 of 2006 concerning the administration of population, in Article 1 Paragraph (1) stating that the Population Administration is a series of activities of structuring and controlling data in the issuance of documents and population data through population registration, civil registration, administration of population administration information and utilization of results for public services and other sectors development. Whereas the registration of population is the recording of population biodata, recording of the reporting of population events and data collection of the population vulnerable population administration and the issuance of residence document in the form of identity card or identity certificate (Article 1 Paragraph 10).

In this case the position of village government in the service of population administration based on the principle of assistance, is contained in Law Number 24 Year 2013 regarding the amendment to Law Number 23 of 2006 concerning the administration of population in Article 7 Paragraph (1) Point $\mathrm{f}$ reads that assignment to village to organize some of the administrative affairs of population based on the principle of assistance task. As stated Fauzan (2006: 69) Assistance principle in the Dutch language called medebewind. The principle of assistance can be interpreted as a grant from the central government / local government with a higher level to be consulted to local governments / lower level government in carrying out the duties or interests which include the affairs of the regional households being asked for assistance. The same thing is also expressed by Sadu (2006: 2) which explains the purpose of providing coadministration is to improve the effectiveness and efficiency of public service delivery to the community. Aims to facilitate the implementation of tasks and problem-solving.

This problem is, of course, related to the service, according to Rasyid (1999) In general, government functions consist of Service, development, empowerment, and arrangement. Village administration is the spearhead in providing services to the community this is contained in Law No. 6 of 2014 on Village, in Article 1 paragraph (2) the village government is the implementation of government affairs and public interest in the system of government of the Unitary State of the Republic of Indonesia. In Article 24 points (h) the implementation of village administration based on the principle of effectiveness and efficiency

The existence of problems in the implementation of population administration services at the village level requires researchers to be able to compare with the village Pangkah Kulon in Gresik Regency that has the best administrative services. Basically, the village government has the same duty and authority between the villages with each other. This is done to see the various advantages of service in the village best practice to look for things that can not be applied to the government of five villages in Kampar regency. Pangkah Kulon Village Ujung Pangkah, Gresik Regency East Java Province is the best village in the field of service. Pangkahkulon Village became the first winner in the best Village Competition in Gresik Regency in 2016. Pangkah Kulon Village managed to win the 3rd place in Village and East Java Village Competition Year 2016. According to East Java Governor Decree No. 188/383 / KPTS / 013 / 2016 About the Winner of East Java Province Village Year 2016 Competition. This will be compared with Intan Jaya village located in Kampar Regency to find various weaknesses in order to find various solutions to the problem of population administration service. This will 
be seen from several aspects, namely: the service standard used, the system and procedures, the development of human resources of the village administration of the facilities that support the provision of services to the village community.

\section{RESEARCH METHODS}

This study uses qualitative research methods using descriptive approach. The choice to use a qualitative approach or method is an attempt to find something that is sometimes difficult to find if using quantitative research methods. Simply qualitative research is a type of research that results in discoveries that can not be achieved (obtained) by using statistical procedures or by other means in the quantification corridor (measurement). Creswell (1994: 1) defines qualitative research as a process of inquiry to understand social problems or human problems, based on the creation of a complete holistic picture formed in words, reporting the informant's views in detail, and arranged in a natural setting. Methods and research approaches were conducted using qualitative research method with a descriptive approach, data collection through observation method, in-depth interview, documentation and focus group discussion. Informant determination technique was done by criterion-based selection technique.

\section{RESULTS AND DISCUSSION}

The existence of problems in the implementation of population administration services in the village of Intan Jaya in Kampar Regency requires researchers to be able to compare with the village Pangkah Kulon in Gresik Regency that has the best administrative services. Basically, the village government has the same duty and authority between the villages with each other. This is done to see the various advantages of service in the village best practice to look for things that can not be applied to the government of five villages in Kampar regency.

This discussion to see the various advantages held by the government of Pangkah Kulon Village located in Gresik regency, East Java. The several aspects used to see it are related to service standards used, systems and procedures, development of human resources governance village facilities that support peasant in the provision of services to the village community. In accordance with the village profile of Pangkah Kulon in 2015 the village area Pangkah Kulon $1,909,8080 \mathrm{Ha}$. The village of Pangkah Kulon in the west is Banyu Urip village, the east is bordered by Pangkah Wetan village, the north is bordered by the Java Sea, the south with the village of Kebon Agung. so that natural resources in the form of fish and shrimp are very abundant because the area close to the sea causes most of the inhabitants of Pangkah Kulon village to work as fishermen. The number of villagers Pangkah Kulon Ujungpangkah subregency recorded until 2015 amounted to 8153 people, with details: a. There are 4,121 men. b. Women as many as 4,032 people.

While Intan Jaya Village is located on the border between two regencies, Rokan Hulu regency with Kampar regency. The total population of Intan Jaya Village is about 1,347 souls with details of 702 male and 645 female. Judging from the population, the number of residents from the village Pangkah Kulon The amount is much more. Ideally, the small number of residents should service better, not the other way around.

Pangkahkulon Village is providing fast, precise, and not in charge and by not complicate the easy affairs. It is expected that the villagers who are mostly middle to lower economic peoples such as farmers, farm workers, farmers, and fishermen do not feel complicated and can facilitate the completion of administrative documents. 30 Seconds Administration Service Innovation in Pangkahkulon Village covers: handling cover letter for making Police Note Certificate (SKCK), residency letter of a resident, letter of loss, general certificate, certificate of KTP, business certificate, certificate of inheritance, forth. This service program has been in 
operation since the beginning of 2016 precisely in January. In operation, this service has application to accelerate the process of settlement of letters, this application is made by Pangkahkulon Village residents own IT expertise, but this application is only internal and offline where Papankulon Village office employees who can access it so that people outside can not access it because it is not linked to other networks. Pangkahkulon Village succeeded in winning the 3rd winner in Village and East Java Village Competition Year 2016. According to the Decree of Governor of East Java Number 188/383 / KPTS / 013/2016 About Winner of Village and East Java Year 2016.

Effective service, indicating the public to follow applicable public service procedures. The procedure in question is the community as the consumer to the village office carrying a letter of introduction from the management of RT, RW or Head of Dusun then the village device will serve the consumer in accordance with the needs or needs. After the service product is completed by the village apparatus, the service consumer can bring the service product to be utilized as needed. The above procedure is clearly defined and implemented from the administrative aspect and is simply understood and implemented by the community in meeting their needs. This will be illustrated in Figure 1.1. about the procedure of service to the public:

Figure 1.1. Village Service Procedures

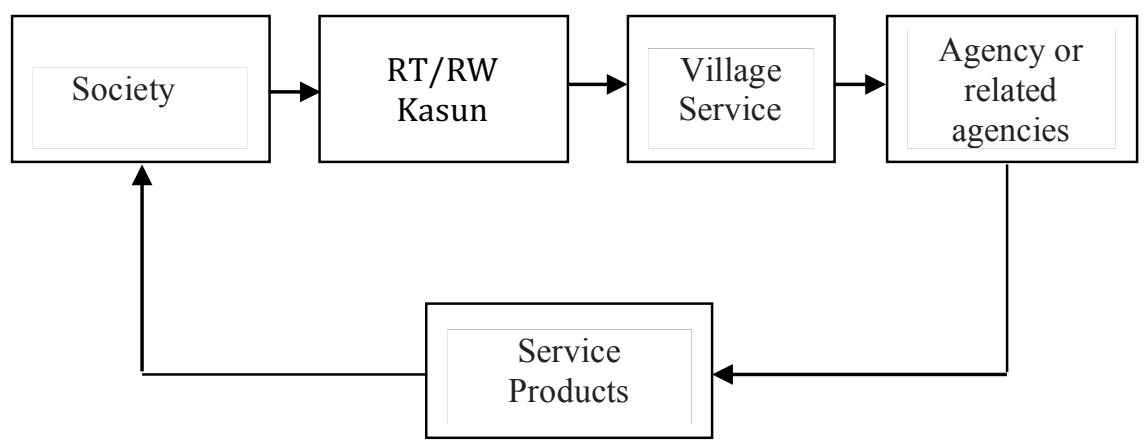

Source: Author, 2017

A large number of service users with varying and diverse needs, the village government can divide the duties and authority of the village apparatus accordingly. As an example of Kasi Pemerintahan and Kaur Umum is assigned for Family Card (KK), Identity Card (KTP) and general administration. While Kasi Kesra is assigned to marriage service. This division clarifies the responsibilities of each village apparatus, whereas the community can easily understand to whom the public asks to be served according to their needs. especially now according to the minister of the Republic of Indonesia's internal affairs regulation number 84 of 2015 on the organizational structure and working procedures of the village government. In Article (5) paragraph (1), (2), and paragraph (3) the technical implementer is the assistant element of the village head as the executor of the operational tasks. most technical implementers consist of 3 (three) sections, namely the government section, welfare section, service section. This, of course, facilitates service to the village community.

Comparison of the best villages in providing population administration services with the condition of the village of Intan Jaya in Kampar regency. Pangkah Kulon Village in Gresik Regency East Java Province is the best village in the field of service. Pangkahkulon village became the first winner in the best village competition in Gresik Regency in 2016. This will be compared with Intan Jaya Village located in Kampar regency. This village was born from the expansion of the region in 1999. to find various weaknesses in order to find various solutions 
related to the problem of population administration services. In Table 1.1. described various differences that occur between villages.

Table 1.1. Comparison of Pangkah Kulon Village, Gresik Regency with Intan Jaya Village in Kampar Regency

\begin{tabular}{|c|c|c|c|}
\hline No. & Aspect & $\begin{array}{l}\text { Pangkah Kulon Village in } \\
\text { Gresik Regency }\end{array}$ & $\begin{array}{l}\text { Intan Jaya Village in } \\
\text { Kampar Regency }\end{array}$ \\
\hline 1. & $\begin{array}{l}\text { Village Government } \\
\text { Administration } \\
\text { Arrangement }\end{array}$ & Well organized & Not Well Organized \\
\hline 2. & Service Standards & $\begin{array}{l}\text { Meet the standard of } \\
\text { service, service time } \\
\text { agreed with the } \\
\text { community }\end{array}$ & $\begin{array}{l}\text { Not Meet the standards, } \\
\text { service time is uncertain }\end{array}$ \\
\hline 3. & Service Procedures & Easy to understand & Difficult to understand \\
\hline 4. & Employee Recruitment & $\begin{array}{l}\text { The existence of a test } \\
\text { mechanism }\end{array}$ & $\begin{array}{l}\text { There is no clear } \\
\text { mechanism yet }\end{array}$ \\
\hline 5. & Service Innovation & $\begin{array}{l}\text { Service only } 30 \text { seconds } \\
\text { (usage of Application) }\end{array}$ & No Innovation \\
\hline 6. & $\begin{array}{l}\text { Complaints/Complaints } \\
\text { Society }\end{array}$ & $\begin{array}{l}\text { In the process quickly to } \\
\text { find a solution, this applies } \\
\text { to the RW / RT level }\end{array}$ & $\begin{array}{l}\text { The absence of a clear } \\
\text { mechanism }\end{array}$ \\
\hline 7. & Spatial Services & It's well organized & Not well organized yet \\
\hline
\end{tabular}

Source: Processed Researcher, Year 2017

This comparison will be seen from various aspects, namely: First, structuring the village government organization Pangkah Kulon in managing the administration of services that are considered very good, because it can enable various village units in carrying out various tasks related to services that are held to the community. While the Village of Intan Jaya in Kampar regency has not been able to arrange service administration because of various problems faced by five villages. This arrangement becomes difficult because the position of the village head is directly appointed by the Kampar regent and only on 20 December 2017 PILKADES is directly conducted by the community. This is enough to affect the organizational structuring and administrative arrangements that are being held. Actually, there are rules that regulate such a regulation of the interior minister of the Republic of Indonesia number 84 of 2015 on the organizational structure and working procedures of the village government.

Secondly, the service standard of Pangkah Kulon Village has fulfilled the requirements such as time certainty, service quality, and friendly employee behavior. In determining the timing of the service, this village had previously conducted various discussions with the community until working hours adjusted to the activities of the majority of the community are farmers. Of course, this is a strategic move. While the implementation of services conducted by the five villages do not meet the standards of service despite the existing rules on the regulation of the interior minister republic Indonesia number 47 of 2016 about village administration,the regulation of the Minister of Home Affairs No. 2 of 2017 concerning the minimum service standard of the village and the regulation of the minister for the empowerment of the state apparatus and the reform of bureaucracy number 15 of 2014 on the standard service guidelines.

Thirdly, the Service Procedure implemented by Pangkah Kulon Village Government is with the principle of participative simple service is not complicated the community as the consumer to 
the village office carrying a letter of introduction from the management of RT, RW or Head of Dusun then the village device will serve the consumers according to their needs. After the service product is completed by the village apparatus, the service consumer can bring the service product to be utilized as needed. The above procedure is clearly defined and implemented from the administrative aspect and is simply understood and implemented by the community in meeting their needs. While the village of Intan Jaya in Kampar regency has not been able to carry out with easy service procedures because many of the people of the community have not understood the procedures of administration clearly.

Fourth, recruitment of employees in Village Pangkah Kulon village head implements the pattern of recruitment of village apparatus by adjusting the rules of recruitment of village apparatus from the government of Gresik Regency, that is by the test system. It is also based on a network of aspirations formed and through various stages. While Village Intan Jaya in Kampar Regency still uses the old pattern without any selection so skill from the employees still needs various training and coaching. Fifth, Village Service Innovation Pangkah Kulon is 30 seconds Administration service in Pangkahkulon Village covering: handling introductory letter for the making of Letter of Introduction of $\mathrm{KK}$, resident domicile, letter of loss, general certificate, certificate of KTP, business certificate, certificate of incompetence. The operation of this service has an application to speed up the process of completion of the letters, this application is made by Pangkahkulon Village residents themselves who have expertise in the field of IT, but this application is only internal and offline where Pangkah Kulon Village office employees who can access it. while Village Intan Jaya in Kampar Regency has no innovation in service to the community.

Sixth, the response of public complaints to the village Pangkah Kulon not only provide a box of criticism and suggestions but to do various solutions related to complaints faced by the community, in addition to convenience, cleanliness, parking space should be arranged in such a way. The criticism and suggestions from the community are discussed in the agenda starting at the level of Kaur, Kasi, Kadus to the level of RW / RT so that various problems around the service can be improved optimally. While the Village Government Intan Jaya in Kampar regency has not a clear complaints mechanism. Ketuju, Tata service village Pangkah Kulon already well ordered; service counter, form filling, waiting room and so on. While the village of Intan Jaya in Kampar regency not yet well ordered as it should be.

\section{CONCLUSION}

Village government in carrying out various duties and functions in serving the community, especially related to the administration of population cannot be held properly. because it needs support from all parties including from local government. The village of Pangkah Kulon Gresik Regency has a larger population while the Village of Intan Jaya has a small population. But in the village public, service Pangkah Kulon can provide the best service to the community, due to the seriousness of the village government and the government of Gresik Regency in encouraging various policy instruments so that the village government to provide innovative services to the community.

Comparisons that have been made between the village governments found some very principal things in the service of the Administration Administration Intan Jaya Village Government is not well ordered, does not meet the standards of service, procedures difficult service to understand the community, recruitment of old system employees, the lack of service innovation, the absence of the system in response to various complaints of the community, not yet the spatial layout of service. It takes the seriousness of the Intan Jaya Village government 
and the Kampar regency government to reorganize the various policy instruments that encourage public service innovation.

\section{Reference}

\section{Books}

Cresswell, John W. 1994. Research Design Qualitative \& Quantitative Approaches. Thousand Oaks: Sage Publication.

Chalik, Abdull and Habibullah, Muttaqin. 2015. Village Public Service, Yogyakarta: SAGAF.

Fauzan, Muhammad. 2006. Local Government Law Studies on Financial Relations Between the Central and Regional Governments. Yogyakarta: UII Press.

Nurcholis, Hanif . 2011. Growth and Implementation of Village Government. Jakarta: Erlangga.

Media Pustaka.

2017. Village Government, Pseudo Government Unit in the Governmental System of NKRI; Jakarta; Bee

Rasyid, Ryaas. 1998. A Trustful Government.Jakarta : Binarena Pariwara.

\section{Regulations}

Law Number 25 the Year 2009 About Public Service.

Regulation of the Minister of Home Affairs Number 2 the Year 2017 concerning Minimum Service Standards Village

Regulation of the Minister of Home Affairs of the Republic of Indonesia Number 47 the Year 2016 About Village Administration

Regulation of the Minister of Home Affairs of the Republic of Indonesia No. 84 of 2015 on Organizational Structure and Administration of Village Governments

Regulation of the Minister of State Apparatus Empowerment and Bureaucracy Reform No. 15 of 2014 on Guidelines for Service Standards. 